\title{
Effects of Straw Return Mode on Soil Aggregates and Associated Carbon in the North China Plain
}

\author{
Shoutian Ma, Zhengrong Kan ${ }^{\circledR}$, Jianying Qi and Hailin Zhang * $\mathbb{D}$ \\ College of Agronomy and Biotechnology, China Agricultural University/Key Laboratory of Farming System, \\ Ministry of Agriculture and Rural Affairs of China, Beijing 100193, China; stma@cau.edu.cn (S.M.); \\ kzr@cau.edu.cn (Z.K.); qijianying@cau.edu.cn (J.Q.) \\ * Correspondence: hailin@cau.edu.cn; Tel./Fax: +86-10-6273-3376
}

Received: 10 December 2019; Accepted: 30 December 2019; Published: 2 January 2020

\begin{abstract}
Crop straw is widely used to manage soil organic carbon (SOC) sequestration as an environmentally friendly practice in the North China Plain. However, little is known about the effects of straw returning modes on SOC sequestration in this region. Thus, a field experiment was conducted to study SOC accumulation and mineralization as well as aggregate stability and aggregate-associated SOC for the following three straw returning modes: no straw returning (NSR), only wheat straw returning (WR), and both wheat and maize straw returning (WR-MR). SOC concentration and storage were higher for WR and WR-MR than for NSR in the $0-20 \mathrm{~cm}$ soil layer, respectively $(p<0.05)$. Although WR and WR-MR resulted in higher mineralization per unit of soil than NSR, no significant difference in mineralization per unit of soil carbon was observed among straw returning modes in the upper soil layer. The mean weight diameters of aggregates at $0-5 \mathrm{~cm}$ were higher under treatments with crop retention than under NSR. At this soil depth, the aggregate-associated $C$ concentration and stock for each soil size were significantly decreased by NSR. These findings suggest that WR-MR and WR are effective residue management practices. In particular, WR is the optimal strategy to enhance SOC sequestration, considering other applications of straw (e.g., forage, fuel, or biomass).
\end{abstract}

Keywords: straw return modes; aggregate; soil organic carbon; sequestration; mineralization

\section{Introduction}

Soil organic carbon (SOC) plays an important role in carbon sequestration and the mitigation of climate change; the amount of carbon (C) stored in soil (1580 Gt C) is two to three times higher than that in the global atmosphere [1-3]. SOC accumulation and sequestration in agro-ecosystems rely on the $\mathrm{C}$ input from crop straw (shoot, root, and root exudates) and $\mathrm{C}$ output from SOC mineralization by soil microbes [4]. In the past, crop straw was widely used for soil amendment, cooking and heating, animal feed, and biofuels; among all these uses, straw returning is considered to be one of the best practices environmentally [5]. Crop straw not only provides a source of fresh organic matter, but also increases crop yield [6]. Any increase (decline) in agronomic yield per unit area leads to high (low) input of biomass $\mathrm{C}$, further increasing (decreasing) soil quality and crop productivity [7]. Long-term field experiments showed that straw returning improves the SOC stock by $0.07-1.46 \mathrm{Mg} \mathrm{ha}^{-1}$ year $^{-1}$ of carbon in northern China [8,9]. However, Zhao et al. [10] evaluated SOC improvement from 1980 to 2011 in China and found that only $16.3 \%$ of the $C$ input derived from crop straw was converted to SOC. Several factors were responsible for low conversion, such as local climatic conditions (temperature and precipitation) and nitrogen fertilization, all of which may have affected mineralization by microbial decomposition [11]. 
Soil aggregates are important physical determinants preventing mineralization in soil due to the physical decrease in the accessibility of organic matter to microorganisms [12,13]. Nearly $90 \%$ of SOC sequestration occurs in soil aggregates [14]; however, SOC is not homogeneously distributed in soil aggregates of different sizes [15]. Soil aggregate stability is an important indicator for assessing SOC accumulation and mineralization. Each size class contains SOC with different degrees of physical protection, through encapsulation, against biodegradation by microbial accessibility, which is further influenced by agricultural management (e.g., straw returning). Soil macro aggregates have a strong ability to protect labile SOC from biodegradation [13], and there is a strong relationship between an increase in macro aggregates and SOC concentration [16]. Thus, the promotion of macro-aggregate formation reduces $C$ output [17]. Straw returning represents an important method to prevent soil erosion, improve soil nutrition, and improve farmland SOC accumulation [18-20]. In addition, crop straw can increase the formation of soil aggregates and the SOC concentration in macro aggregates [6]. However, previous studies have not identified any positive effects of straw returning on soil aggregates [21]. For example, Bossuyt et al. [22] argued that macro-aggregate formation was significantly affected by fungal activity rather than crop straw. These inconsistent results suggest that the effects of crop residues on soil aggregation in agricultural soils are related to the choice of management practices based on different locations and crops.

There are about 18 million hectares of farmland in the North China Plain (NCP). The grain yield in the NCP accounts for about $30 \%$ of the total output in China. However, with increasing demand for cereal crops, intensive agricultural practices (e.g., tillage, irrigation, and nitrogen fertilization) were adopted, thereby accelerating the degradation of existing organic matter. Traditional straw burning has recently been replaced by straw returning to effectively re-use agricultural waste and to enhance carbon sequestration and improve soil fertility. It was estimated that the amount of straw input in the NCP was higher than in the other regions (e.g., Northeast and Southern China), while the SOC storage was lower [10]. Thus, it is important to adopt suitable straw returning management measures to improve the soil structure and promote the sustainable development of agriculture in the NCP. In this region, the dominant cropping system is winter wheat rotated with summer maize. Wheat and maize straw have different chemical properties (e.g., carbon: nitrogen ratios and nutrient content), which affect the rates of mineralization and decomposition due to differences in nutrient availability for microbial growth [23]. Thus, SOC accumulation and mineralization can differ under wheat and maize straw returning based on local climatic conditions. However, the effects of straw returning modes (e.g., double-season crop straw returning or single-season crop returning) on SOC accumulation and mineralization in the double cropping system are still unclear in the NCP [20]. In addition, crop straw not only functions as a fertilizer to improve soil quality and enhance soil carbon sequestration but is also an important forage resource for livestock [24]. Thus, the rational use of straw resources is important in a multiple-cropping system.

The specific objectives of this study were to (i) assess SOC accumulation and mineralization as well as their relationship under different straw returning modes, (ii) identify the effects of straw returning on aggregate size distribution and stability, and (iii) clarify the effects of straw returning on aggregate-associated concentration and stock. We hypothesized that straw returning (double- or single-season crop returning) will enhance macro-aggregate formation and the associated C concentration.

\section{Material and Methods}

\subsection{Experimental Site}

The field experiment was conducted from 2015 to 2017 at the Wuqiao Experimental Station of the China Agricultural University $\left(37^{\circ} 36^{\prime} \mathrm{N}, 116^{\circ} 21^{\prime} \mathrm{E}\right)$, which is located in the NCP in Hebei Province. The station is in a temperate continental climate zone, with a mean annual air temperature of $13.1{ }^{\circ} \mathrm{C}$, and precipitation of $531.1 \mathrm{~mm}$ (of which about $76 \%$ occurs from June to September). 
The average temperature and precipitation during the research period are shown in Figure 1 . The soil type is silt loam (18.62\% sand, $70.20 \%$ silt, and $11.18 \%$ clay at $0-20 \mathrm{~cm}$ depth) according to the USDA classification. The basic properties (0-20 cm soil layers measured in 2015) are as follows: $1.35 \mathrm{~g} \mathrm{~cm}^{-3}$ bulk density, $10.34 \mathrm{~g} \mathrm{~kg}^{-1} \mathrm{SOC}, 0.79 \mathrm{~g} \mathrm{~kg}^{-1}$ total nitrogen, $94.2 \mathrm{mg} \mathrm{kg}^{-1}$ available potassium (K), and $44.6 \mathrm{mg} \mathrm{kg}^{-1}$ available phosphorus (P). The main local cropping system is winter wheat and summer maize double cropping.

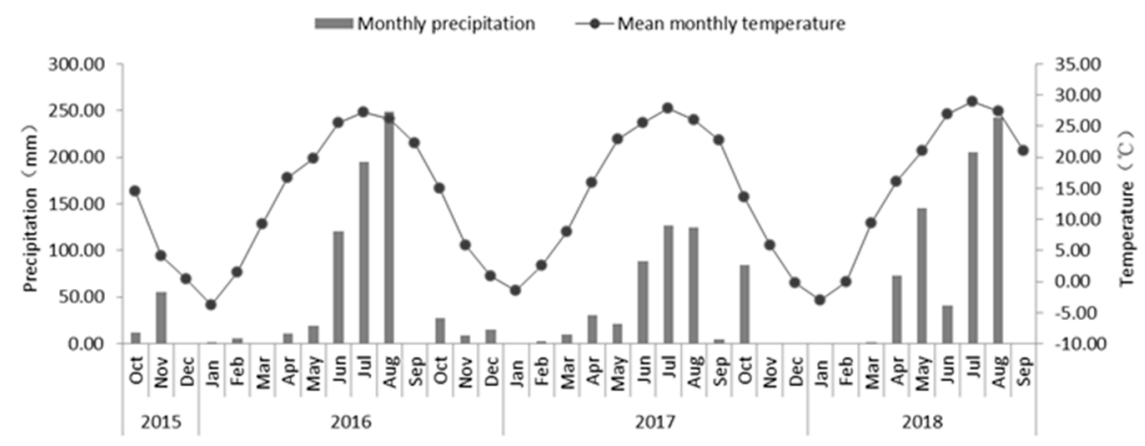

Figure 1. Average temperature and precipitation during the research period at Wuqiao Station, Hebei province, China.

\subsection{Experimental Design}

Summer maize (mid-June to early October, Longping 208) and winter wheat (October to June of the next year, Jimai 22) were rotated each year. The treatment began during the wheat season in October 2015. Three treatments were implemented as follows: (1) no straw returning (NSR), (2) only wheat straw returning (WR), and (3) both wheat and maize straw returning (WR-MR). Under NSR, the aboveground straw was all removed manually after harvest, with very little stubble returned to the field. Under straw returning, the straw crop was cut into 10-cm-long segments and uniformly distributed over each plot after harvest. The rates of straw returned are shown in Table 1. Each treatment was replicated three times following a completely random design over a total of nine plots $(7 \mathrm{~m} \times 25 \mathrm{~m}$ each plot).

Table 1. The rate of straw returned to the field.

\begin{tabular}{|c|c|c|c|}
\hline Year & Treatments & Maize Straw $\left(\mathrm{kg} \cdot \mathrm{ha}^{-1}\right)$ & Wheat Straw $\left(\mathrm{kg} \cdot \mathrm{ha}^{-1}\right)$ \\
\hline \multirow{3}{*}{ 2015.10-2016.10 } & NSR & 0 & 0 \\
\hline & WR & 0 & 7250 \\
\hline & WR-MR & 11,432 & 9167 \\
\hline \multirow{3}{*}{ 2016.10-2017.10 } & NSR & 0 & 0 \\
\hline & WR & 0 & 10,175 \\
\hline & WR-MR & 10,970 & 10,800 \\
\hline
\end{tabular}

NSR, no straw returning; WR, only wheat straw returning; WR-MR, both wheat and maize straw returning.

After the maize harvest, the entire soil surface of all plots was tilled twice with a rotavator $(\sim 15 \mathrm{~cm}$ depth), and the maize straw was crushed and incorporated into the surface soil of the straw returning treatments by rotary tillage (WR-MR treatment). The same rate and type of chemical fertilizers were applied. In the wheat season, around $243 \mathrm{~kg} \mathrm{~N} \mathrm{ha}^{-1}, 103.5 \mathrm{~kg} \mathrm{P} \mathrm{ha}^{-1}$, and $107 \mathrm{~kg} \mathrm{~K} \mathrm{ha}^{-1}$ (corresponding to urea, diammonium phosphate, and potassium sulfate) were applied as base fertilizer. In addition, $75 \mathrm{~kg} \mathrm{~N} \mathrm{ha}^{-1}$ urea was surface broadcasted at the wheat jointing stage. In the maize season, $525 \mathrm{~kg} \mathrm{ha}^{-1}$ of compound fertilizer $\left(\mathrm{N}: \mathrm{P}_{2} \mathrm{O}_{5}: \mathrm{K}_{2} \mathrm{O}=22: 8: 10\right)$ was applied. Two or three separate irrigation events ranging from 70 to $80 \mathrm{~mm}$ each were necessary during the winter wheat season. 


\subsection{Soil Sampling and Measurements}

\subsubsection{Soil Aggregates}

Soil samples for water-stable aggregate (WSA) and bulk density analyses were collected from depths of $0-5,5-10,10-20,20-30$, and 30-50 $\mathrm{cm}$ in each plot $(\mathrm{n}=16)$ using a $100 \mathrm{~cm}^{3}$ core. Separate samples were obtained for WSA and bulk soil analyses after maize harvests in 2016 and 2017. The samples were air-dried and stored in plastic bags [25]. For the wet-sieving method, the air-dried soil samples were separated into four aggregate size fractions $(>2,0.25-2,0.053-0.25$, and $<0.053 \mathrm{~mm})$. Handle-stacked sieves were mounted on an instrument similar to a Yoder-type sieve [26] following the methods described by Chen [27]. Fine floating particles $(<0.053 \mathrm{~mm})$ in distilled water were collected by filtration. The soils were collected using a sieve, then dried at $60{ }^{\circ} \mathrm{C}$ for $24 \mathrm{~h}$, and then weighed. The mean weight diameter (MWD) and geometric mean diameter (GMD) of the soil aggregates were determined as follows [15]:

$$
\mathrm{MWD}=\sum_{i=1}^{n} x_{i} w_{i}
$$

where $x_{i}$ is the mean aggregate diameter of each size class $(\mathrm{mm})$ and $w_{i}$ is the weight percentage of each size of aggregates. Macro aggregates were defined as fractions of $>2 \mathrm{~mm}$ and $0.25-2 \mathrm{~mm}$, and micro aggregates were defined as fractions of $0.053-0.25 \mathrm{~mm}$.

$$
\mathrm{GMD}=\exp \left(\frac{\sum_{i=1}^{n} w_{i} \log x_{i}}{\sum_{i=1}^{n} w_{i}}\right)
$$

where $w_{i}$ indicates the total dry weight of the aggregates, $n$ indicates the number of sieves, and $x_{i}$ indicates the mean diameter of aggregates over each sieve size.

\subsubsection{Soil Analysis}

Soil samples and subsamples from each particle-size aggregate were passed through a $0.25 \mathrm{~mm}$ sieve and analyzed for SOC and aggregate-associated $C$, determined via $\mathrm{K}_{2} \mathrm{Cr}_{2} \mathrm{O}_{7}$ oxidation and titration with $\mathrm{Fe}_{2} \mathrm{SO}_{4}$ [28]. SOC storage was calculated as follows based on the equivalent soil depth [29]:

$$
\mathrm{M}_{\mathrm{element}}=\mathrm{BD} \times \mathrm{T} \times \text { conc } \times 0.1
$$

where $\mathrm{M}_{\text {element }}$ represents SOC storage $\left(\mathrm{Mg} \mathrm{ha}^{-1}\right)$, BD represents the bulk density, $\mathrm{T}$ is the thickness of the soil layer, and conc is the soil organic $C$ concentration $\left(\mathrm{g} \mathrm{kg}^{-1}\right)$. Similar to bulk soil, SOC storage in aggregates was determined by multiplying $\mathrm{M}_{\text {element }}$ by the proportion of each size class.

\subsection{Incubation Experiment}

In air-tight $330 \mathrm{~mL}$ jars, fresh soil samples (equivalent to $40 \mathrm{~g}$ air-dried soil) were kept at $70 \%$ of the water holding capacity. After pre-incubation for 7 days, all jars were maintained at $25^{\circ} \mathrm{C}$ for 60 days. The released $\mathrm{CO}_{2}$ was trapped by $1 \mathrm{M} \mathrm{NaOH}$, and potentially mineralized $\mathrm{C}$ was measured as $\mathrm{CO}_{2}$ emissions by titrating the remaining $\mathrm{NaOH}$ with $\mathrm{HCl}$; the results are expressed as $\mathrm{mg} \mathrm{CO}_{2}-\mathrm{C} \mathrm{kg}^{-1}$ of soil [30].

\subsection{Statistical Analysis}

A one-way ANOVA was used to study the effects of straw returning modes during the same year for all datasets. All data were analyzed using SPSS 20.0 (SPSS Inc., Chicago, IL, USA). The mean differences between treatments were determined by Duncan's new multiple range test with a significance threshold of $p<0.05$ for the measured soil variables. 


\section{Results}

\subsection{Effects of Straw Return Modes on the SOC Concentration and Storage}

Significant differences in the SOC concentration were observed under different straw returning modes in the upper $20 \mathrm{~cm}$ soil layer compared with the 20-50 cm layer (Table 2). The WR and WR-MR had higher SOC concentrations than NSR by $32.0-35.2 \%$ and $37.2-40.8 \%$, respectively, in the $0-5 \mathrm{~cm}$ soil layer; by $33.1-39.0 \%$ and $33.5-45.2 \%$, respectively, in the $5-10 \mathrm{~cm}$ soil layer; and by $53.3-55.0 \%$ and $37.4-50.7 \%$, respectively, in the $10-20 \mathrm{~cm}$ soil layer $(p<0.05)$. No significant differences were observed between treatments in the $20-30$ and $30-50 \mathrm{~cm}$ soil layers. Similar to the SOC concentration, high SOC storage was observed under WR and WR-MR compared with NSR by $27.1-31.2 \%$ and $27.5-36.6 \%$, respectively, in the $0-5 \mathrm{~cm}$ soil layer; by $27.0-30.0 \%$ and $28.2-39.5 \%$, respectively, in the $5-10 \mathrm{~cm}$ soil layer; and by $60.0-61.3 \%$ and $44.6-48.4 \%$, respectively, in the $10-20 \mathrm{~cm}$ soil layer $(p<0.05)$. Overall, residue returning (WR and WR-MR) significantly improved the SOC concentration and storage in the upper $20 \mathrm{~cm}$ soil layer.

Table 2. The SOC concentration and storage under different straw return modes.

\begin{tabular}{|c|c|c|c|c|c|c|}
\hline \multirow{2}{*}{$\begin{array}{c}\text { Year } \\
\text { Treatments }\end{array}$} & \multicolumn{3}{|c|}{2016} & \multicolumn{3}{|c|}{2017} \\
\hline & $\mathrm{BD}\left(\mathrm{g} \mathrm{cm}^{-3}\right)$ & SOC $\left(\mathrm{g} \mathrm{kg}^{-1}\right)$ & $\begin{array}{l}\text { SOC Storage } \\
\left(\mathrm{Mg} \mathrm{ha}^{-1}\right)\end{array}$ & $\mathrm{BD}\left(\mathrm{g} \mathrm{cm}^{-3}\right)$ & SOC $\left(\mathrm{g} \mathrm{kg}^{-1}\right)$ & $\begin{array}{l}\text { SOC Storage } \\
\left(\mathrm{Mg} \mathrm{ha}^{-1}\right)\end{array}$ \\
\hline \multicolumn{7}{|l|}{$0-5 \mathrm{~cm}$} \\
\hline NSR & 1.39 & $7.25 b$ & $5.03 b$ & 1.30 & $7.88 \mathrm{~b}$ & $5.12 b$ \\
\hline WR & 1.30 & $9.80 \mathrm{a}$ & $6.39 a$ & 1.29 & $10.40 \mathrm{a}$ & $6.72 \mathrm{a}$ \\
\hline WR-MR & 1.29 & $9.95 a$ & $6.41 \mathrm{a}$ & 1.26 & $11.10 \mathrm{a}$ & $7.00 \mathrm{a}$ \\
\hline \multicolumn{7}{|l|}{$5-10 \mathrm{~cm}$} \\
\hline NSR & 1.37 & $7.18 b$ & $4.91 \mathrm{~b}$ & 1.36 & $7.73 b$ & $5.26 \mathrm{~b}$ \\
\hline WR & 1.36 & $9.98 \mathrm{a}$ & $6.24 \mathrm{a}$ & 1.33 & $10.29 a$ & $6.84 a$ \\
\hline WR-MR & 1.32 & $9.58 \mathrm{a}$ & $6.30 \mathrm{a}$ & 1.31 & $11.23 a$ & $7.35 a$ \\
\hline \multicolumn{7}{|l|}{$10-20 \mathrm{~cm}$} \\
\hline NSR & 1.43 & $4.04 \mathrm{c}$ & $5.79 \mathrm{c}$ & 1.40 & $4.37 \mathrm{~b}$ & $6.10 \mathrm{~b}$ \\
\hline WR & 1.49 & $6.19 a$ & $9.27 \mathrm{a}$ & 1.45 & $6.77 \mathrm{a}$ & $9.84 a$ \\
\hline WR-MR & 1.51 & $5.55 \mathrm{~b}$ & $8.38 \mathrm{~b}$ & 1.38 & $6.58 \mathrm{a}$ & $9.05 a$ \\
\hline \multicolumn{7}{|l|}{$20-30 \mathrm{~cm}$} \\
\hline NSR & 1.48 & $4.04 a$ & $5.97 a$ & 1.42 & $4.96 a$ & $7.04 a$ \\
\hline WR & 1.59 & $3.76 a$ & $6.41 \mathrm{a}$ & 1.48 & $4.68 \mathrm{a}$ & $6.94 a$ \\
\hline WR-MR & 1.55 & $4.12 \mathrm{a}$ & $6.41 \mathrm{a}$ & 1.48 & $4.88 \mathrm{a}$ & $7.24 \mathrm{a}$ \\
\hline \multicolumn{7}{|l|}{$30-50 \mathrm{~cm}$} \\
\hline NSR & 1.42 & $3.98 \mathrm{a}$ & $11.33 a$ & 1.47 & $3.57 \mathrm{a}$ & $10.48 \mathrm{a}$ \\
\hline WR & 1.55 & $3.83 a$ & $11.85 \mathrm{a}$ & 1.55 & $3.87 \mathrm{a}$ & $11.96 \mathrm{a}$ \\
\hline WR-MR & 1.41 & $3.70 \mathrm{a}$ & $10.41 \mathrm{a}$ & 1.48 & $3.52 \mathrm{a}$ & $10.40 \mathrm{a}$ \\
\hline
\end{tabular}

NSR, no straw returning; WR, only wheat straw returning; WR-MR, both wheat and maize straw returning. Lower case letters indicate significant differences $(p<0.05)$ among different treatments within the same soil depth.

\subsection{Effects of Straw Return Modes on SOC Mineralization}

Cumulative mineralization showed a decreasing trend as soil depth increased, and the straw returning mode significantly affected cumulative mineralization in the upper $20 \mathrm{~cm}$ soil layer compared with the 20-50 cm layer (Figure 2). Cumulative mineralization was higher for WR-MR than for WR and NSR by $5.0 \%$ and $38.8 \%$, respectively, in the $0-5 \mathrm{~cm}$ soil layer, by $15.9 \%$ and $46.0 \%$, respectively, in the $5-10 \mathrm{~cm}$ soil layer, and by $32.7 \%$ and $21.9 \%$, respectively, in the $10-20 \mathrm{~cm}$ soil layer $(p<0.05)$. No significant differences were observed in cumulative mineralization in the $20-30 \mathrm{~cm}$ and $30-50 \mathrm{~cm}$ soil layers. A significant linear correlation was observed between cumulative mineralization and the SOC concentration $\left(R^{2}=0.66, p<0.001\right)$, indicating that a high SOC concentration was related to high potential losses (Figure 3). Considering the basal SOC concentration, mineralization/SOC showed 
increasing trends as soil depth increased. Significant differences were observed in the 10-20 cm soil layers, and higher mineralization/SOC was observed under WR-MR and NSR than under WR by $49.1 \%$ and $67.9 \%$, respectively $(p<0.05)$.

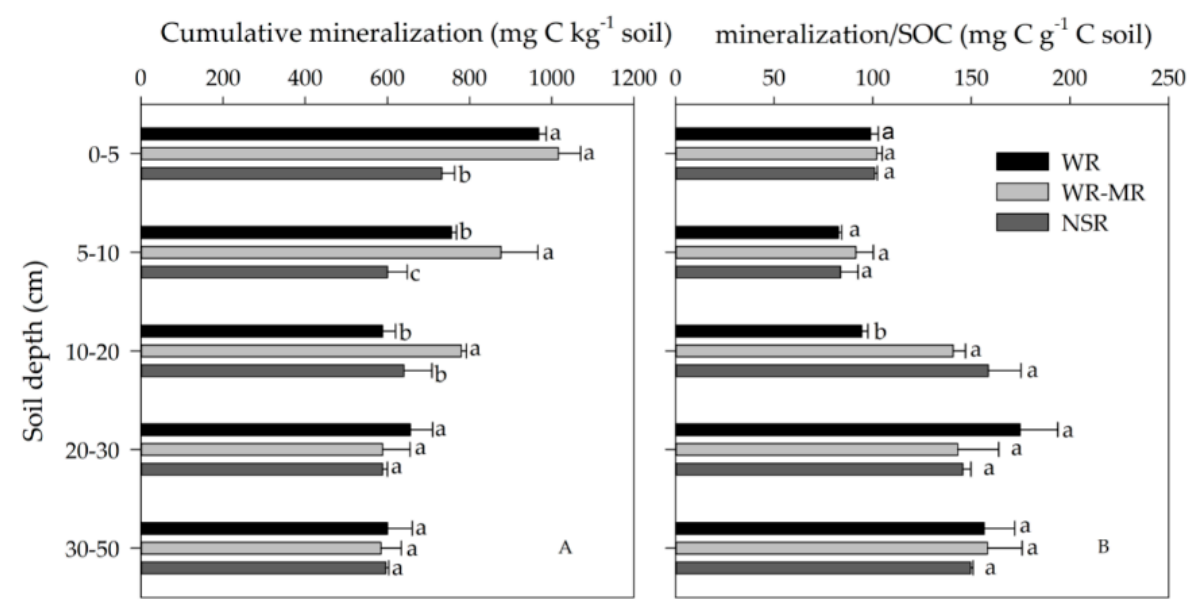

Figure 2. Effects of straw return modes on cumulative mineralization (A) and SOC/mineralization (B). NSR, no straw returning; WR, only wheat straw returning; WR-MR, both wheat and maize straw returning. Lower case letters indicate significant differences $(p<0.05)$ among different treatments within the same soil depth. Error bars indicate SD.

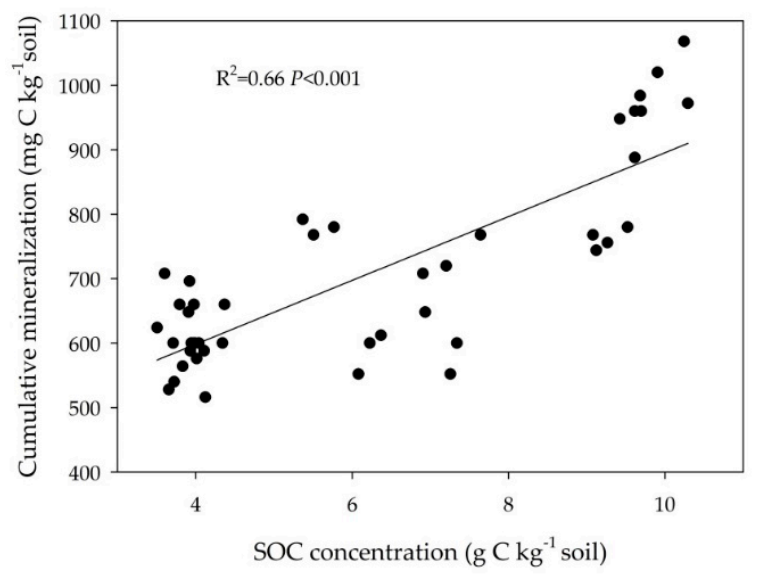

Figure 3. Correlation between SOC concentration and cumulative mineralization.

\subsection{Effects of Straw Return Modes on the Particle Size Distribution and Stability of Soil Aggregates}

In 2016, MWD values under NSR (0.30-0.44) were significantly lower than those under WR and WR-MR at 0-5, 5-10, and 10-20 cm soil depths (Table 3). However, there were no significant differences in GMD among treatments. For the 20-30 and 30-50 cm soil layers, there were no significant differences in MWD and GMD among treatments. In 2017, at 0-5, 5-10, 10-20, and 20-30 cm soil depths, the MWD under NSR was still lower than those under the other treatments. However, there were no significant differences in GMD among treatments at 0-5 and 5-10 cm soil depths.

In 2016, the proportions of soil aggregates with particle sizes of $0.25-2 \mathrm{~mm}$ and $<0.053 \mathrm{~mm}$ at the $0-5 \mathrm{~cm}$ soil depth were significantly higher under NSR than under WR-MR. For both $0-5 \mathrm{~cm}$ and 5-10 cm soil depths, the WR-MR treatment tended to accumulate soil aggregates of $>2 \mathrm{~mm}$, as shown by the significantly higher proportion of this fraction. There was a similar trend in 2017 at these two soil depths. In addition, for the deeper soil layers, the proportion of $>2 \mathrm{~mm}$ soil aggregate was still comparatively higher under WR-MR, in both 2016 and 2017. 
Table 3. Effects of straw return modes on aggregate size distribution and stability.

\begin{tabular}{|c|c|c|c|c|c|c|c|c|c|c|c|c|}
\hline \multirow{3}{*}{$\begin{array}{c}\text { Year } \\
\text { Treatments }\end{array}$} & \multicolumn{6}{|c|}{2016} & \multicolumn{6}{|c|}{2017} \\
\hline & \multicolumn{4}{|c|}{ Percentage (\%) } & \multirow{2}{*}{$\begin{array}{l}\text { MWD } \\
(\mathrm{mm})\end{array}$} & \multirow{2}{*}{$\begin{array}{l}\text { GMD } \\
(\mathrm{mm})\end{array}$} & \multicolumn{4}{|c|}{ Percentage (\%) } & \multirow{2}{*}{$\begin{array}{c}\text { MWD } \\
\text { (mm) }\end{array}$} & \multirow{2}{*}{$\begin{array}{l}\text { GMD } \\
(\mathrm{mm})\end{array}$} \\
\hline & $>2 \mathrm{~mm}$ & $0.25-2 \mathrm{~mm}$ & $0.053-0.25 \mathrm{~mm}$ & $<0.053 \mathrm{~mm}$ & & & $>2 \mathrm{~mm}$ & $0.25-2 \mathrm{~mm}$ & $0.053-0.25 \mathrm{~mm}$ & $<0.053 \mathrm{~mm}$ & & \\
\hline \multicolumn{13}{|l|}{$0-5 \mathrm{~cm}$} \\
\hline NSR & $4.06 \mathrm{~b}$ & $24.74 a$ & $32.00 \mathrm{~b}$ & $39.20 \mathrm{a}$ & $0.41 \mathrm{~b}$ & $0.49 a$ & $24.62 \mathrm{c}$ & 21.04a & $13.86 \mathrm{~b}$ & $35.99 a$ & $0.87 \mathrm{~b}$ & $0.63 \mathrm{a}$ \\
\hline WR & $4.19 \mathrm{~b}$ & $24.83 a$ & $32.70 \mathrm{~b}$ & $38.28 \mathrm{~b}$ & $0.45 a$ & $0.48 \mathrm{a}$ & $30.80 \mathrm{~b}$ & $19.16 \mathrm{~b}$ & $15.37 \mathrm{a}$ & $34.66 \mathrm{~b}$ & $0.95 a$ & $0.66 \mathrm{a}$ \\
\hline WR-MR & $5.50 \mathrm{a}$ & $23.22 b$ & $36.25 a$ & $35.03 c$ & $0.44 a$ & $0.48 \mathrm{a}$ & $40.09 a$ & $15.78 \mathrm{c}$ & $11.03 \mathrm{c}$ & $33.37 \mathrm{c}$ & $0.89 \mathrm{~b}$ & $0.62 \mathrm{a}$ \\
\hline \multicolumn{13}{|l|}{$5-10 \mathrm{~cm}$} \\
\hline NSR & $4.40 \mathrm{c}$ & $21.90 \mathrm{a}$ & $42.28 \mathrm{a}$ & $31.41 \mathrm{c}$ & $0.44 \mathrm{~b}$ & $0.49 a$ & $30.21 \mathrm{c}$ & $19.89 a$ & 14.18a & $35.71 \mathrm{a}$ & $0.87 \mathrm{~b}$ & $0.63 \mathrm{a}$ \\
\hline WR & $7.04 \mathrm{~b}$ & $22.21 \mathrm{a}$ & $32.97 \mathrm{~b}$ & $37.77 \mathrm{a}$ & $0.49 a$ & $0.50 \mathrm{a}$ & $34.75 \mathrm{~b}$ & $17.20 \mathrm{~b}$ & $13.15 b$ & $34.91 \mathrm{a}$ & $0.93 \mathrm{~b}$ & $0.65 \mathrm{a}$ \\
\hline WR-MR & $8.72 a$ & $22.45 a$ & $33.25 b$ & $35.58 \mathrm{~b}$ & $0.48 \mathrm{a}$ & $0.49 a$ & $37.44 \mathrm{a}$ & $17.48 \mathrm{~b}$ & $12.11 \mathrm{c}$ & $32.96 \mathrm{~b}$ & $0.98 \mathrm{a}$ & $0.67 \mathrm{a}$ \\
\hline \multicolumn{13}{|l|}{$10-20 \mathrm{~cm}$} \\
\hline NSR & $2.67 \mathrm{c}$ & $15.44 \mathrm{~b}$ & $33.42 \mathrm{c}$ & $48.47 a$ & $0.30 \mathrm{~b}$ & $0.42 \mathrm{a}$ & $33.66 \mathrm{~b}$ & $14.07 \mathrm{c}$ & $14.24 \mathrm{~b}$ & $38.03 a$ & $0.87 \mathrm{~b}$ & $0.61 \mathrm{~b}$ \\
\hline WR & $4.38 \mathrm{a}$ & $16.51 \mathrm{a}$ & $34.14 b$ & $44.97 \mathrm{~b}$ & $0.34 \mathrm{a}$ & $0.44 a$ & $22.64 \mathrm{c}$ & $19.77 \mathrm{a}$ & $17.19 a$ & $40.40 \mathrm{a}$ & $0.72 \mathrm{c}$ & $0.56 \mathrm{c}$ \\
\hline WR-MR & $3.64 \mathrm{~b}$ & $16.21 \mathrm{a}$ & $35.68 \mathrm{a}$ & $44.47 \mathrm{~b}$ & $0.33 a$ & $0.43 a$ & $43.26 \mathrm{a}$ & $15.85 b$ & $13.12 \mathrm{c}$ & $32.73 b$ & $1.03 a$ & $0.67 \mathrm{a}$ \\
\hline \multicolumn{13}{|l|}{$20-30 \mathrm{~cm}$} \\
\hline NSR & $1.72 \mathrm{a}$ & $11.91 \mathrm{~b}$ & $34.22 \mathrm{~b}$ & $52.15 a$ & $0.25 a$ & $0.39 a$ & $8.30 \mathrm{~b}$ & $13.51 \mathrm{a}$ & $19.37 \mathrm{~b}$ & $58.82 \mathrm{a}$ & $0.38 b$ & $0.42 \mathrm{~b}$ \\
\hline WR & $1.35 \mathrm{~b}$ & $12.30 \mathrm{a}$ & $34.32 \mathrm{~b}$ & $52.04 a$ & $0.27 a$ & $0.39 a$ & $7.82 \mathrm{~b}$ & $13.58 \mathrm{a}$ & $22.13 a$ & $56.48 \mathrm{~b}$ & $0.37 \mathrm{~b}$ & $0.42 \mathrm{~b}$ \\
\hline WR-MR & $1.59 \mathrm{a}$ & $11.78 \mathrm{~b}$ & $35.25 \mathrm{a}$ & $51.38 \mathrm{~b}$ & $0.25 \mathrm{a}$ & $0.39 a$ & $19.13 a$ & $10.45 b$ & $20.13 b$ & $55.62 \mathrm{~b}$ & $0.59 \mathrm{a}$ & $0.48 \mathrm{a}$ \\
\hline \multicolumn{13}{|l|}{$30-50 \mathrm{~cm}$} \\
\hline NSR & $1.21 \mathrm{a}$ & $10.78 \mathrm{c}$ & $31.73 c$ & $56.28 \mathrm{a}$ & $0.24 a$ & $0.39 a$ & $3.82 \mathrm{c}$ & $10.43 b$ & $22.96 a$ & $62.79 a$ & $0.35 a$ & $0.40 \mathrm{a}$ \\
\hline WR & $1.21 \mathrm{a}$ & $11.10 \mathrm{~b}$ & $35.54 \mathrm{a}$ & $52.15 \mathrm{~b}$ & $0.23 a$ & $0.39 a$ & $5.98 \mathrm{~b}$ & $11.58 \mathrm{a}$ & $22.06 \mathrm{a}$ & $60.38 b$ & $0.32 a$ & $0.40 \mathrm{a}$ \\
\hline WR-MR & $1.25 \mathrm{a}$ & $12.19 \mathrm{a}$ & $33.53 b$ & $53.03 b$ & $0.22 \mathrm{a}$ & $0.38 a$ & $8.28 \mathrm{a}$ & $11.41 \mathrm{a}$ & $18.41 \mathrm{~b}$ & $61.90 \mathrm{a}$ & $0.26 \mathrm{~b}$ & $0.38 \mathrm{a}$ \\
\hline
\end{tabular}

NSR, no straw returning; WR, only wheat straw returning; WR-MR, both wheat and maize straw returning. MWD, mean weight diameter; GMD, geometric mean diameter. Lower case letters indicate significant differences $(p<0.05)$ among different treatments within the same soil depth. 


\subsection{Effects of Straw Return Modes on Aggregate-Associated SOC Concentration}

At the $0-5 \mathrm{~cm}$ soil depth, the SOC concentrations for $>2 \mathrm{~mm}$ soil aggregates were significantly higher under WR-MR than under NSR, in both 2016 and 2017 (Table 4). At the 5-10 cm soil depth, the concentration for $>2 \mathrm{~mm}$ soil aggregates was $11.27 \mathrm{~g} \mathrm{~kg}^{-1}$ under WR-MR, which was significantly higher than those for NSR and WR in 2016 and significantly higher than that for NSR in 2017, indicating that WR-MR promoted SOC accumulation. For the deep soil layers, the results for each treatment differed between 2016 and 2017. For instance, the SOC concentrations for $>2 \mathrm{~mm}$ and $0.25-2 \mathrm{~mm}$ soil aggregates were significantly lower under WR-MR than under the other treatments in 2016, but the opposite results were found in 2017. There were no significant differences for $20-30$ and 30-50 cm soil depths among treatments in 2016.

Table 4. Effects of straw return modes on aggregate-associated C concentration.

\begin{tabular}{|c|c|c|c|c|c|c|c|c|}
\hline \multirow{2}{*}{$\begin{array}{c}\text { Year } \\
\text { Treatments }\end{array}$} & \multicolumn{4}{|c|}{2016} & \multicolumn{4}{|c|}{2017} \\
\hline & $>2 \mathrm{~mm}$ & $0.25-2 \mathrm{~mm}$ & $0.053-0.25 \mathrm{~mm}$ & $<0.053 \mathrm{~mm}$ & $>2 \mathrm{~mm}$ & $0.25-2 \mathrm{~mm}$ & $0.053-0.25 \mathrm{~mm}$ & $<0.053 \mathrm{~mm}$ \\
\hline \multicolumn{9}{|l|}{$0-5 \mathrm{~cm}$} \\
\hline NSR & $8.09 c$ & $9.66 c$ & $6.77 \mathrm{c}$ & $5.86 \mathrm{~b}$ & $8.71 \mathrm{~b}$ & $10.12 \mathrm{c}$ & $9.08 b$ & $8.42 \mathrm{c}$ \\
\hline WR & $10.33 b$ & $10.71 b$ & $8.56 b$ & $8.33 a$ & $11.87 \mathrm{a}$ & $12.85 \mathrm{a}$ & $11.52 \mathrm{a}$ & $11.28 \mathrm{a}$ \\
\hline \multicolumn{9}{|l|}{$5-10 \mathrm{~cm}$} \\
\hline NSR & $7.97 \mathrm{c}$ & $9.21 \mathrm{c}$ & $6.43 c$ & $6.05 c$ & $9.26 \mathrm{~b}$ & $9.10 \mathrm{~b}$ & $6.17 \mathrm{c}$ & $8.89 c$ \\
\hline WR & $10.53 b$ & $10.74 b$ & $7.80 \mathrm{~b}$ & $8.35 a$ & $11.82 \mathrm{a}$ & $12.82 \mathrm{a}$ & $10.86 \mathrm{~b}$ & $11.01 \mathrm{~b}$ \\
\hline WR-MR & $11.27 \mathrm{a}$ & $11.90 \mathrm{a}$ & $8.49 \mathrm{a}$ & $7.99 \mathrm{~b}$ & $11.51 \mathrm{a}$ & $12.66 \mathrm{a}$ & $11.22 \mathrm{a}$ & $11.27 \mathrm{a}$ \\
\hline \multicolumn{9}{|l|}{$10-20 \mathrm{~cm}$} \\
\hline \multicolumn{9}{|l|}{$20-30 \mathrm{~cm}$} \\
\hline NSR & $4.45 \mathrm{a}$ & $4.27 \mathrm{a}$ & $3.57 \mathrm{a}$ & $3.61 \mathrm{a}$ & $4.25 b$ & $3.96 b$ & $4.85 b$ & $4.46 c$ \\
\hline WR & $4.22 \mathrm{a}$ & $4.27 \mathrm{a}$ & $3.33 \mathrm{a}$ & $3.46 \mathrm{a}$ & $7.93 a$ & $7.48 \mathrm{a}$ & $7.40 \mathrm{a}$ & $6.91 \mathrm{a}$ \\
\hline WR-MR & $4.36 a$ & $4.25 a$ & $3.49 \mathrm{a}$ & $3.50 \mathrm{a}$ & $7.84 a$ & $7.41 \mathrm{a}$ & $7.06 a$ & $7.11 \mathrm{a}$ \\
\hline \multicolumn{9}{|l|}{$30-50 \mathrm{~cm}$} \\
\hline NSR & $4.39 \mathrm{a}$ & $4.00 \mathrm{a}$ & $3.69 \mathrm{a}$ & $3.57 \mathrm{ab}$ & $4.40 \mathrm{c}$ & $3.97 \mathrm{c}$ & $3.40 \mathrm{c}$ & $3.24 b$ \\
\hline WR & $4.23 \mathrm{a}$ & $3.96 a$ & $3.21 b$ & $3.39 b$ & $7.63 b$ & $7.05 b$ & $6.65 b$ & $6.44 \mathrm{a}$ \\
\hline WR-MR & $4.20 \mathrm{a}$ & $3.74 \mathrm{a}$ & $3.51 \mathrm{a}$ & $3.64 a$ & $8.03 a$ & $7.62 a$ & $7.12 \mathrm{a}$ & $6.72 a$ \\
\hline
\end{tabular}

NSR, no straw returning; WR, only wheat straw returning; WR-MR, both wheat and maize straw returning. Lower case letters indicate significant differences $(p<0.05)$ among different treatments within the same soil depth.

\subsection{Effects of Straw Returning Modes on Aggregate-Associated SOC Storage}

In 2016 and 2017, the aggregate-associated C at the $0-5 \mathrm{~cm}$ soil depth under NSR was comparatively lower at each aggregate size compared with the other treatments (Table 5). At this soil depth, the estimates for the $>2$-mm soil aggregates were 0.39 and $2.88 \mathrm{Mg} \mathrm{ha}^{-1}$ in 2016 and 2017, which were significantly higher than those for the other treatments. At the $5-10 \mathrm{~cm}$ soil depth, the SOC stock of $>2 \mathrm{~mm}, 0.25-2 \mathrm{~mm}$ and $0.053-0.25 \mathrm{~mm}$ soil aggregates ranged from 0.65 to $2.82 \mathrm{Mg} \mathrm{ha}^{-1}$, which were higher under WR-MR in both years. At the 5-10 cm soil depth, the SOC stocks for $>2 \mathrm{~mm}$, $0.25-2 \mathrm{~mm}$, and $0.053-0.25 \mathrm{~mm}$ soil aggregates were also comparatively higher under WR-MR than under other treatments. 
Table 5. Effects of straw return modes on aggregate-associated C storage.

\begin{tabular}{|c|c|c|c|c|c|c|c|c|}
\hline \multirow{3}{*}{$\begin{array}{c}\text { Year } \\
\text { Treatments }\end{array}$} & \multicolumn{4}{|c|}{2016} & \multicolumn{4}{|c|}{2017} \\
\hline & \multicolumn{4}{|c|}{ Aggregate-Associated C Storage $\left(\mathrm{Mg} \mathrm{ha}^{-1}\right)$} & \multicolumn{4}{|c|}{ Aggregate-Associated C Storage (Mg ha $\left.{ }^{-1}\right)$} \\
\hline & $>2 \mathrm{~mm}$ & $0.25-2 \mathrm{~mm}$ & $0.053-0.25 \mathrm{~mm}$ & $<0.053 \mathrm{~mm}$ & $>2 \mathrm{~mm}$ & $0.25-2 \mathrm{~mm}$ & $0.053-0.25 \mathrm{~mm}$ & $<0.053 \mathrm{~mm}$ \\
\hline \multicolumn{9}{|l|}{$0-5 \mathrm{~cm}$} \\
\hline NSR & $0.23 c$ & $1.66 c$ & $1.50 \mathrm{c}$ & $1.59 \mathrm{c}$ & $1.39 \mathrm{c}$ & $1.38 \mathrm{~b}$ & $0.82 b$ & $1.97 \mathrm{c}$ \\
\hline WR & $0.28 b$ & $1.74 \mathrm{~b}$ & $1.83 b$ & $2.08 \mathrm{a}$ & $2.36 \mathrm{~b}$ & $1.59 \mathrm{a}$ & $1.14 \mathrm{a}$ & $2.53 a$ \\
\hline WR-MR & $0.39 a$ & $1.87 \mathrm{a}$ & $2.21 \mathrm{a}$ & $1.95 \mathrm{a}$ & $2.88 \mathrm{a}$ & $1.23 \mathrm{c}$ & $0.80 \mathrm{~b}$ & $2.26 \mathrm{~b}$ \\
\hline \multicolumn{9}{|l|}{$5-10 \mathrm{~cm}$} \\
\hline NSR & $0.24 \mathrm{c}$ & $1.38 \mathrm{c}$ & $1.86 \mathrm{a}$ & $1.30 \mathrm{c}$ & $1.90 \mathrm{~b}$ & $1.23 b$ & $0.60 \mathrm{~b}$ & $2.16 \mathrm{c}$ \\
\hline WR & $0.51 b$ & $1.63 b$ & $1.75 b$ & $2.15 \mathrm{a}$ & $2.73 a$ & $1.47 \mathrm{a}$ & $0.95 a$ & $2.56 a$ \\
\hline WR-MR & $0.65 a$ & $1.76 \mathrm{a}$ & $1.86 a$ & $1.87 \mathrm{~b}$ & $2.82 \mathrm{a}$ & $1.45 \mathrm{a}$ & $0.89 \mathrm{a}$ & $2.43 b$ \\
\hline \multicolumn{9}{|l|}{$10-20 \mathrm{~cm}$} \\
\hline NSR & $0.17 \mathrm{c}$ & $1.66 \mathrm{~b}$ & $2.65 a$ & $3.43 a$ & $3.18 \mathrm{c}$ & $1.47 \mathrm{c}$ & $1.60 \mathrm{c}$ & $4.60 \mathrm{~b}$ \\
\hline WR & $0.50 \mathrm{a}$ & $1.86 \mathrm{a}$ & $2.65 a$ & $3.21 b$ & $3.38 b$ & $3.12 \mathrm{a}$ & $2.35 a$ & $5.35 a$ \\
\hline WR-MR & $0.35 b$ & $1.61 \mathrm{~b}$ & $2.72 a$ & $3.08 b$ & $6.07 \mathrm{a}$ & $2.40 \mathrm{~b}$ & $1.82 \mathrm{~b}$ & $4.35 c$ \\
\hline \multicolumn{9}{|l|}{$20-30 \mathrm{~cm}$} \\
\hline NSR & $0.11 \mathrm{a}$ & $0.75 b$ & $1.81 \mathrm{a}$ & $2.79 a$ & $0.50 \mathrm{c}$ & $0.76 c$ & $1.33 c$ & $3.72 b$ \\
\hline WR & $0.09 a$ & $0.83 a$ & $1.81 \mathrm{a}$ & $2.86 \mathrm{~b}$ & $0.92 b$ & $1.50 \mathrm{a}$ & $2.42 a$ & $5.78 \mathrm{a}$ \\
\hline WR-MR & $0.11 \mathrm{a}$ & $0.78 \mathrm{ab}$ & $1.91 \mathrm{a}$ & $2.80 \mathrm{~b}$ & $2.22 \mathrm{a}$ & $1.15 b$ & $2.11 b$ & $5.87 \mathrm{a}$ \\
\hline \multicolumn{9}{|l|}{$30-50 \mathrm{~cm}$} \\
\hline NSR & $0.15 a$ & $1.23 \mathrm{~b}$ & $3.33 a$ & $5.72 \mathrm{a}$ & $0.49 \mathrm{c}$ & $1.21 \mathrm{~b}$ & $2.29 \mathrm{c}$ & $5.97 \mathrm{~b}$ \\
\hline WR & $0.16 a$ & $1.36 \mathrm{a}$ & $3.53 a$ & $5.46 a$ & $1.41 \mathrm{~b}$ & $2.52 a$ & $4.54 \mathrm{a}$ & $12.02 \mathrm{a}$ \\
\hline WR-MR & $0.15 a$ & $1.28 \mathrm{ab}$ & $3.31 \mathrm{a}$ & $5.43 a$ & $1.97 \mathrm{a}$ & $2.57 \mathrm{a}$ & $3.87 \mathrm{~b}$ & $12.30 \mathrm{a}$ \\
\hline
\end{tabular}

\section{Discussion}

\subsection{SOC Storage and Mineralization}

In the present study, crop residues significantly improved SOC concentration and storage, in accordance with the results of Zhao et al. [10], who found a linear relationship between the cumulative residue C input and SOC increment. However, a larger SOC increment only occurred in the $0-20 \mathrm{~cm}$ soil layer, and no significant difference was observed in the $30-50 \mathrm{~cm}$ soil layer. This could be explained by the fact that that the mixing of crop straw by rotary tillage only occurred up to $10-15 \mathrm{~cm}$ in our study. Furthermore, SOC storage did not differ significantly between double-season (maize and wheat) and single-season (wheat) straw returning, indicating that the input of maize straw did not effectively improve SOC accumulation. The $\mathrm{C} / \mathrm{N}$ ratios for maize straw were found to be higher than for wheat straw in previous studies e.g., [31], and high $\mathrm{C} / \mathrm{N}$ ratios affect microbial SOC conversion, making SOC decomposition difficult [32]. A significant correlation was observed between the SOC concentration and cumulative mineralization, indicating that straw returning with a high SOC concentration stimulated soil $\mathrm{C}$ loss. The addition of crop straw could increase microbial biomass and activity [33], thereby promoting SOC decomposition. However, considering the basal SOC concentration, crop residues did not increase cumulative mineralization per unit of SOC, and WR even decreased it in the $0-5 \mathrm{~cm}$ and $10-20 \mathrm{~cm}$ soil layers, which may explain the higher SOC accumulation under straw returning. The use of crop residues for sustainable agricultural development involves a balance between soil quality and other uses (e.g., cellulosic feedstock) [20]. Thus, after meeting the demand for improvements in soil quality, maize straw in the WR could have many other uses, such as forage, fuel, and biomass.

\subsection{Aggregate Size Distribution and Associated C}

Assessments of aggregate size distribution can reveal the physical structure of soil and reflect soil quality. Soil aggregate stability could be easily described and explained by the parameters GMD and 
MWD [34], which directly describe soil agglomeration and degradation [35] as well as potential soil nutrient supplementation [36]. Higher GMD and MWD values are associated with low soil erosion and disturbance [37]. Thus, a larger number of macro aggregates ( $>2 \mathrm{~mm}$ soil aggregates) indicates the stability of the soil structure. The results of our study showed that WR-MR and WR significantly increased soil MWD in the 0-10 cm soil layer in 2016 (a similar trend was observed in 2017), indicating that residue retention was positive for soil aggregate formation. Moreover, our results indicated that WR-MR increased the proportion of $>2 \mathrm{~mm}$ soil aggregates, even in deeper soil layers. Thus, the benefits of crop residue retention are not restricted to the upper soil layer, and future studies should evaluate the mechanism underlying SOC sequestration at deep soil layers.

Additionally, for the formation and stabilization of aggregates, SOC, microbial biomass, and soil protein are critical. Generally, macro aggregates are more likely to be formed around fresh SOC, which provide the $C$ source for microbial activity to produce soil binders [13]. Therefore, crop straw retention can increase the supply of $C$ required for aggregate formation [38]. This explains the higher proportion of $>2 \mathrm{~mm}$ soil aggregates observed under MR-WR and WR. Additionally, according to our results, WR-MR is beneficial due to its $C$ accumulation capacity in the surface soil layer, especially for $>2 \mathrm{~mm}$ soil aggregates, which is consistent with previous results showing that residue retention improves both $C$ storage and soil structure [39]. $C$ inputs affect $C$ storage [40], as verified by the comparison among treatments in our study. In turn, SOC in macro aggregates was less sensitive to decomposition by chemical, physical, and biological effects [41]. Therefore, the higher abundance of $>2 \mathrm{~mm}$ soil aggregates may contribute to SOC accumulation or stabilization under treatments with residue retention (WR and MR-WR). In addition, the results of our study showed that NSR decreased the aggregate-associated $\mathrm{C}$ stock and SOC concentration for each aggregate size. Thus, this treatment is not recommended in this region according to our findings.

\section{Conclusions}

This study investigated SOC accumulation and mineralization as well as aggregate stability and associated SOC under different straw returning modes. Straw returning (WR-MR and WR) resulted in significantly higher MWD than that for NSR and improved the aggregate-associated C concentration and storage for each soil aggregate size in the upper soil layer. Thus, WR and WR-MR significantly increased SOC storage compared with NSR. Furthermore, no significant difference in mineralization per unit of soil carbon was observed among different straw returning modes. These findings suggest that WR-MR and WR are effective strategies to enhance aggregate stability and SOC accumulation in the NCP, and WR is the optimal choice due to the potential applications of using the remaining maize straw (e.g., for forage or marsh gas) without affecting soil carbon sequestration.

Author Contributions: Conceptualization, S.M. and H.Z.; methodology, S.M. and J.Q.; investigation, S.M. and Z.K.; data curation, S.M.; formal analysis, S.M.; visualization, S.M.; writing—original draft preparation, S.M., Z.K., and J.Q.; writing-editing, Z.K., J.Q., and H.Z.; supervision, H.Z.; project administration, H.Z.; funding acquisition, H.Z. All authors have read and agreed to the published version of the manuscript.

Funding: This research was financially supported by Special Fund for Agro-scientific Research in the Public Interest in China (201503136).

Acknowledgments: This work is grateful to all the staff of the Wuqiao Experimental Station of China Agricultural University for their help in obtaining the data. Special thanks go to the anonymous reviewers for their constructive comments in improving this manuscript.

Conflicts of Interest: The authors declare no conflict of interest.

\section{References}

1. Wang, X.J.; Chen, G.H.; Wang, S.Y.; Zhang, L.Y.; Zhang, R. Temperature sensitivity of different soil carbon pools under biochar addition. Environ. Sci. Pollut. Res. 2019, 26, 4130-4140. [CrossRef] [PubMed]

2. Scharlemann, J.P.W.; Tanner, E.V.J.; Hiederer, R.; Kapos, V. Global soil carbon: Understanding and managing the largest terrestrial carbon pool. Carbon Manag. 2014, 5, 81-91. [CrossRef] 
3. Jobbagy, E.G.; Jackson, R.B. The vertical distribution of soil organic carbon and its relation to climate and vegetation. Ecol. Appl. 2000, 10, 423-436. [CrossRef]

4. Xie, J.Y.; Hou, M.M.; Zhou, Y.T.; Wang, R.J.; Zhang, S.L.; Yang, X.Y.; Sun, B.H. Carbon sequestration and mineralization of aggregate-associated carbon in an intensively cultivated Anthrosol in north China as affected by long term fertilization. Geoderma 2017, 296, 1-9. [CrossRef]

5. Zhao, X.; Liu, B.Y.; Liu, S.L.; Qi, J.Y.; Wang, X.; Pu, C.; Li, S.S.; Zhang, X.Z.; Yang, X.G.; Lal, R.; et al. Sustaining crop production in China's cropland by crop residue retention: A meta-analysis. Land Degrad. Dev. 2019. [CrossRef]

6. Liu, C.; Lu, M.; Cui, J.; Li, B.; Fang, C. Effects of straw carbon input on carbon dynamics in agricultural soils: A meta-analysis. Glob. Chang. Biol. 2014, 20, 1366-1381. [CrossRef]

7. Lal, R. Sequestering carbon and increasing productivity by conservation agriculture. J. Soil Water Conserv. 2015, 70, 55a-62a. [CrossRef]

8. Htun, Y.M.; Tong, Y.A.; Gao, P.C.; Ju, X.T. Coupled effects of straw and nitrogen management on $\mathrm{N}_{2} \mathrm{O}$ and $\mathrm{CH}_{4}$ emissions of rainfed agriculture in Northwest China. Atmos. Environ. 2017, 157, 156-166. [CrossRef]

9. Zhang, W.J.; Wang, X.J.; Xu, M.G.; Huang, S.M.; Liu, H.; Peng, C. Soil organic carbon dynamics under long-term fertilizations in arable land of northern China. Biogeosciences 2010, 7, 409-425. [CrossRef]

10. Zhao, Y.; Wang, M.; Hu, S.; Zhang, X.; Ouyang, Z.; Zhang, G.; Huang, B.; Zhao, S.; Wu, J.; Xie, D.; et al. Economics- and policy-driven organic carbon input enhancement dominates soil organic carbon accumulation in Chinese croplands. Proc. Natl. Acad. Sci. USA 2018, 115, 4045-4050. [CrossRef]

11. Huang, R.; Tian, D.; Liu, J.; Lv, S.; He, X.; Gao, M. Responses of soil carbon pool and soil aggregates associated organic carbon to straw and straw-derived biochar addition in a dryland cropping mesocosm system. Agric. Ecosyst. Environ. 2018, 265, 576-586. [CrossRef]

12. Gao, L.; Wang, B.; Li, S.; Wu, H.; Wu, X.; Liang, G.; Gong, D.; Zhang, X.; Cai, D.; Degré, A. Soil Wet Aggregate Distribution and Pore Size Distribution Under Different Tillage Systems After 16 Years in the Loess Plateau of China. Catena 2019, 38-47. [CrossRef]

13. Six, J.; Elliott, E.T.; Paustian, K. Soil macroaggregate turnover and microaggregate formation: A mechanism for C sequestration under no-tillage agriculture. Soil Biol. Biochem. 2000, 32, 2099-2103. [CrossRef]

14. Jastrow, J.D. Soil aggregate formation and the accrual of particulate and mineral-associated organic matter. Soil Biol. Biochem. 1996, 28, 665-676. [CrossRef]

15. Wang, X.; Qi, J.Y.; Zhang, X.Z.; Li, S.S.; Virk, A.L.; Zhao, X.; Xiao, X.P.; Zhang, H.L. Effects of tillage and residue management on soil aggregates and associated carbon storage in a double paddy cropping system. Soil Tillage Res. 2019, 194, 104339. [CrossRef]

16. Plaza-Bonilla, D.; Cantero-Martinez, C.; Alvaro-Fuentes, J. Tillage effects on soil aggregation and soil organic carbon profile distribution under Mediterranean semi-arid conditions. Soil Use Manag. 2010, 26, 465-474. [CrossRef]

17. Lugato, E.; Simonetti, G.; Morari, F.; Nardi, S.; Berti, A.; Giardini, L. Distribution of organic and humic carbon in wet-sieved aggregates of different soils under long-term fertilization experiment. Geoderma 2010, 157, 80-85. [CrossRef]

18. Bandyopadhyay, P.K.; Saha, S.; Mani, P.K.; Mandal, B. Effect of organic inputs on aggregate associated organic carbon concentration under long-term rice-wheat cropping system. Geoderma 2010, 154, 379-386. [CrossRef]

19. Chen, Z.D.; Ti, J.S.; Chen, F. Soil aggregates response to tillage and residue management in a double paddy rice soil of the Southern China. Nutr. Cycl. Agroecol. 2017, 109, 103-114. [CrossRef]

20. Zhao, H.L.; Shar, A.G.; Li, S.; Chen, Y.L.; Shi, J.L.; Zhang, X.Y.; Tian, X.H. Effect of straw return mode on soil aggregation and aggregate carbon content in an annual maize-wheat double cropping system. Soil Tillage Res. 2018, 175, 178-186. [CrossRef]

21. Soon, Y.K.; Lupwayi, N.Z. Straw management in a cold semi-arid region: Impact on soil quality and crop productivity. Field Crops Res. 2012, 139, 39-46. [CrossRef]

22. Bossuyt, H.; Denef, K.; Six, J.; Frey, S.D.; Merckx, R.; Paustian, K. Influence of microbial populations and residue quality on aggregate stability. Appl. Soil Ecol. 2001, 16, 195-208. [CrossRef]

23. Dimassi, B.; Mary, B.; Fontaine, S.; Perveen, N.; Revaillot, S.; Cohan, J.P. Effect of nutrients availability and long-term tillage on priming effect and soil C mineralization. Soil Biol. Biochem. 2014, 78, 332-339. [CrossRef]

24. Lal, R. World crop residues production and implications of its use as a biofuel. Environ. Int. 2005, 31, 575-584. [CrossRef] [PubMed] 
25. Arai, M.; Minamiya, Y.; Tsuzura, H.; Watanabe, Y.; Yagioka, A.; Kaneko, N. Changes in water stable aggregate and soil carbon accumulation in a no-tillage with weed mulch management site after conversion from conventional management practices. Geoderma 2014, 221, 50-60. [CrossRef]

26. Yoder, R.E. A Direct Method of Aggregate Analysis of Soils and a Study of the Physical Nature of Erosion Losses. Agron. J. 1936, 28, 337-351. [CrossRef]

27. Chen, C.; Liu, W.; Wu, J.; Jiang, X.; Zhu, X. Can intercropping with the cash crop help improve the soil physico-chemical properties of rubber plantations? Geoderma 2019, 335, 149-160. [CrossRef]

28. Bao, S.D. Methods for Soil Agricultural and Chemical Analysis; Chinese Agricultural Press: Beijing, China, 2000; pp. 30-34.

29. Ellert, B.H.; Bettany, J.R. Calculation of organic matter and nutrients stored in soils under contrasting management regimes. Can. J. Soil Sci. 1995, 75, 529-538. [CrossRef]

30. Raiesi, F.; Kabiri, V. Carbon and nitrogen mineralization kinetics as affected by tillage systems in a calcareous loam soil. Ecol. Eng. 2017, 106, 24-34. [CrossRef]

31. Dai, H.; Chen, Y.; Liu, K.; Li, Z.; Qian, X.; Zang, H.; Yang, X.; Zhao, Y.; Shen, Y.; Li, Z.; et al. Water-stable aggregates and carbon accumulation in barren sandy soil depend on organic amendment method: A three-year field study. J. Clean. Prod. 2019, 212, 393-400. [CrossRef]

32. Kan, Z.-R.; Virk, A.L.; Wu, G.; Qi, J.-Y.; Ma, S.-T.; Wang, X.; Zhao, X.; Lal, R.; Zhang, H.-L. Priming effect intensity of soil organic carbon mineralization under no-till and residue retention. Appl. Soil Ecol. 2019, 103445. [CrossRef]

33. Fang, Y.; Nazaries, L.; Singh, B.K.; Singh, B.P. Microbial mechanisms of carbon priming effects revealed during the interaction of crop residue and nutrient inputs in contrasting soils. Glob. Chang. Biol. 2018, 24, 2775-2790. [CrossRef] [PubMed]

34. Kemper, W.D.; Rosenau, R.C. Aggregate Stability and Size Distribution. In: Methods of Soil Analysis, Part 1. Physical and Mineralogical Methods (2nd Edition). Agron. Monogr. 1986, 9, 425-442.

35. Barthes, B.; Roose, E. Aggregate stability as an indicator of soil susceptibility to runoff and erosion; validation at several levels. Catena 2002, 47, 133-149. [CrossRef]

36. Bronick, C.J.; Lal, R. Soil structure and management: A review. Geoderma 2005, 124, 3-22. [CrossRef]

37. Piccolo, A.; Pietramellara, G.; Mbagwu, J.S.C. Use of humic substances as soil conditioners to increase aggregate stability. Geoderma 1997, 75, 267-277. [CrossRef]

38. Verhulst, N.; Kienle, F.; Sayre, K.D.; Deckers, J.; Raes, D.; Limon-Ortega, A.; Tijerina-Chavez, L.; Govaerts, B. Soil quality as affected by tillage-residue management in a wheat-maize irrigated bed planting system. Plant Soil. 2011, 340, 453-466. [CrossRef]

39. Blanco-Canqui, H. Crop Residue Removal for Bioenergy Reduces Soil Carbon Pools: How Can We Offset Carbon Losses? BioEnergy Res. 2013, 6, 358-371. [CrossRef]

40. Autret, B.; Mary, B.; Chenu, C.; Balabane, M.; Girardin, C.; Bertrand, M.; Grandeau, G.; Beaudoin, N. Alternative arable cropping systems: A key to increase soil organic carbon storage? Results from a 16 year field experiment. Agric. Ecosyst. Environ. 2016, 232, 150-164. [CrossRef]

41. O'Brien, S.L.; Jastrow, J.D. Physical and chemical protection in hierarchical soil aggregates regulates soil carbon and nitrogen recovery in restored perennial grasslands. Soil Biol. Biochem. 2013, 61, 1-13. [CrossRef]

(C) 2020 by the authors. Licensee MDPI, Basel, Switzerland. This article is an open access article distributed under the terms and conditions of the Creative Commons Attribution (CC BY) license (http://creativecommons.org/licenses/by/4.0/). 